\title{
Eradication of Porcine Sarcoptic Mange within a Health Declared Production Model
}

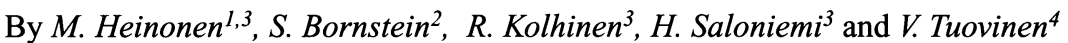

${ }^{1}$ LSO Foods Ltd, University of Helsinki, Saarentaus, Finland, ${ }^{2}$ Department of Parasitology (SWEPAR), National Vetertinary Institute Uppsala, Sweden, ${ }^{3}$ Department of Clinical Veterinary Sciences, Faculty of Veterinary Medicine, University of Helsinki, and ${ }^{4}$ Lihakunta, Kuopio, Finland.

\begin{abstract}
Heinonen M, Bornstein S, Kolhinen R, Saloniemi H, Tuovinen V: Eradication of porcine sarcoptic mange within a health declared production model. Acta vet. scand. 2000, 41, 41-50. - The success of a large-scale eradication programme against sarcoptic mange was evaluated in piglet producing herds belonging to the health class LSO 2000. These farms are monitored to be free from sarcoptic mange, swine enzootic pneumoniae, swine dysentery and progressive atrophic rhinitis. The local veterinarians were instructed to eradicate sarcoptic mange from the herds by 2 ivermectin injections 14 days apart or 3 treatments with phoxim pour-on 6 days apart before the farms were able to join the health class. The study consisted of a questionnaire administered to the farmers, farm visits and follow-ups associated with the regular control of the health class. A questionnaire was sent to all of the 379 accepted farrowing farms. Altogether 323 farmers had initiated an eradication programme at least 7 months before the questionnaire was distributed and $96 \%$ of them believed that the mange eradication programme had been successful. In most of the successful herds ( $90 \%)$, the local veterinarian had treated the animals by the recommended methods, and the majority of the farmers $(88 \%)$ had cleaned and sprayed the pens with insecticides on the days of treatment. Three out of the 7 unsuccessful farms had employed methods other than those recommended. Twenty-five herds were randomly selected for an intensified control. The rubbing index was $\leq 0.1$ in all herds visited, indicating freedom from mange. Sows or gilts, 15-20 animals per farm, were skin scraped and no Sarcoptes scabiei was found. The same animals were blood sampled and serum antibodies to $S$. scabiei were measured by an indirect ELISA. All except 1 farm had low optical density (OD) values in most of the samples. The owner of that farm had become uncertain about the mange status of the herd and had recently retreated all animals with acaricides. The number of complaints about mange in the finishing units buying health class feeder pigs was low. The study demonstrates that it is possible to run an eradication programme against sarcoptic mange, in which a large number of farmers together with their veterinarians participate. It is possible to eradicate mange not only at the herd but also at the population level. The ELISA test employed proved to be a possible tool to monitor the efficacy of mange-eradication programmes.
\end{abstract}

pig; Sarcoptes scabiei; rubbing index; skin scrapings; ELISA; LSO 2000.

\section{Introduction}

Sarcoptes scabiei var suis infections are widespread in pig populations around the world. A high proportion of pig herds (70\%-90\%) are affected (Dobson \& Davies 1992). In Finnish stu- dies, $90 \%$ of herds were found to be mange positive (Tuovinen et al. 1994) and $94 \%$ of the herd owners treated their animals with acaricides (Oksanen 1989). The fact that sarcoptic 
mange can be eradicated from swine herds is well established although eradication programmes are usually concerned with a small number of herds, i.e., 1 to 4 herds/study (Henriksen \& Ebbesen 1987, Jensen et al. 1988, Madsen 1988, Oksanen \& Tuovinen 1990, Lambers 1994). In one study (Jensen 1988) 22 herds were involved and all of them succeeded in eradicating mange. However, producers have tolerated S.scabiei infection in their herds. Only after the farmers started to get a better price for their disease-free piglets did they get interested in eradicating the parasite.

In Finland, the owners of the finishing units usually purchase feeder pigs from a dealer, whose stock is derived from several small farrowing herds. This system has been the only practical way of economically arranging a feeder pig supply for finishing units (Tuovinen et al. 1997a). The probability of a finishing unit receiving pigs with for example mange has been practically $100 \%$ (Tuovinen 1994). In an effort to control diseases and decrease drug usage a health class system (LSO 2000, Tuovinen et al. 1997b) was initiated by Southwestern Finland's Cooperative Slaughterhouse (LSO), nowadays LSO Foods Ltd. The farms specialised in rearing feeder pigs for the LSO 2000 health class are strictly monitored to be free from sarcoptic mange, swine enzootic pneumoniae, swine dysentery and progressive atrophic rhinitis. The system is comparable with the specific pathogen free (SPF) system. However, freedom from the diseases is obtained by methods other than caesarean section. A regimen of frequent veterinary visits and control by the animal health service of the slaughterhouse ensures freedom from the diseases. In case of mange in the finishing unit, veterinary and medicine costs are covered by the warranty given by LSO.

There are 3 different forms of sarcoptic mange: the acute disease with erythematous skin pa- pules and pruritus, chronic mange with thickened skin and crusts over the body, and subclinical mange with only a few or no outward signs of infection (Martineau et al. 1987a, Martineau et al. 1987b, Bornstein 1995). The basic feature of acute mange lesions is that they develop and then regress (Cargill \& Dobson 1979).

It has been shown that the hosts have an immune response to Sarcoptes mites (Wooten \& Gaafar 1984, Morsy \& Gaafar 1989, Nöckler et al. 1992, Bornstein \& Zakrisson 1993). According to Bornstein \& Zakrisson (1993), demonstration of serum antibodies (ELISA) to $S$. scabiei can discriminate infected from uninfected animals. That method has been used to monitor the success of eradication attempts in single herds (Jacobsson et al. 1999), but it has not been used to evaluate the success of a largescale eradication programme.

The objective of this study was to monitor the success of a large-scale eradication programme of sarcoptic mange in farrowing units in the LSO 2000 health class. The benefits of the programme for individual farms were estimated by the owners of the farrowing units. Another objective was to test if the above mentioned ELISA (Bornstein \& Zakrisson 1993) could be used in monitoring the efficacy of an eradication programme for sarcoptic mange.

\section{Materials and methods}

The LSO 2000 system and the methods used in eradicating sarcoptic mange

Since 1990, the local veterinarians in southwestern Finland have been advised by the animal health service of LSO Foods Ltd to eradicate sarcoptic mange from swine herds using 2 ivermectin injections (Ivomec ${ }^{\circledR}$, Merck, Sharp \& Dohme B.V., Haarlem, the Netherlands, 300 $\mathrm{mcg} / \mathrm{kg}$ ) 14 days apart (Hogg 1989). Since 1991, phoxim pour-on (Sebacil Pour-on ${ }^{\circledR}$, Bayer AG, Leverkusen, Germany, $30 \mathrm{mg} / \mathrm{kg}$ ) has also been available to the veterinarians and 
they have been advised to use it for all pigs in the herd 3 times 6 days apart (Madsen 1988). In 1994, the LSO 2000 health class (Tuovinen et al. 1997b) was introduced for the farrowing farms. The farms had to be free from mange, documented by the local veterinarian before they could join the health class. The numbers of farrowing units, feeder pigs sold and complaints because of sarcoptic mange in finishing units buying feeder pigs within the system were recorded for the years 1995-1997. The local practitioners monitored the farrowing units in the health class for signs of sarcoptic mange, enzootic pneumoniae, swine dysentery and progressive atrophic rhinitis at least 4 times a year with a maximum interval of 3 months. If the herds were considered to be clinically free from these diseases the veterinarian signed a certificate after each visit. If the quality officer did not get a certificate every 3 months, the farrowing unit was dropped to the unknown health status category (standard class). The feeder pigs from the health-classified farrowing units were not mixed with standard class feeder pigs at any time. They were sorted into the pens of the "all in - all out" finishing units by source farrowing units. Thus, feeder pigs from different farrowing units were in principle not mixed in the same pens making it easier to trace any possibly infected farrowing unit after an outbreak of sarcoptic mange in a finishing unit.

\section{Design of monitoring by questionnaire and by herd visits}

In January 1996, a one-page questionnaire was sent to all farrowing units, which had been accepted into the health class ( 379 herds). The questionnaire contained pre-coded answers about the medications and cleaning of the facilities during the mange eradication programme and the success of the eradication. The answers concerning the size of the herd, possible reason for the failure of the programme and the bene- fits for the farm from the programme were open-ended. An answer to the questionnaire was obtained from all herds: 341 farmers (90\%) posted a written answer and the ones that did not reply were interviewed by telephone (10\%). Only the herds which had started the eradication programme at least 7 months earlier were included in the study ( 323 herds).

Twenty-five out of the 312 farms where eradication was successful and where at least 7 months had passed since the beginning of the programme were selected at random and visited in March 1996. During a farm visit clinical signs of sarcoptic mange were recorded. A group of $10-15$ gilts or sows was observed for $15 \mathrm{~min}$. The number of recorded rubbing episodes was divided by the number of pigs observed to yield the rubbing index (Madsen 1988). Special interest was paid to an additional 15-20 sows or gilts aged at least 5 months. Most of them were adults. These animals were skin scraped with a sharp knife in the outer ear canal and examined for presence of mange mites under a light microscope within $12 \mathrm{~h}$. In addition, blood samples were collected from the vena auricularis or vena caudalis medialis of these animals. The sera was stored at $-18^{\circ} \mathrm{C}$ until assayed. A previously described indirect enzyme-linked immunosorbent assay (ELISA) was used to detect serum antibodies to $S$. scabiei (Bornstein \& Wallgren 1997).

\section{Results}

The questionnaire and the control in the health class

In 323 farms (85\%) a mange-eradication programme had been initiated at least 7 months earlier, and in 23 farms $(6 \%)$ that time period was less than 7 months. The remaining 33 farms $(9 \%)$ had been declared mange-free by the local veterinarian. The animals had not expressed any clinical signs of sarcoptic mange and the farmers had not used any acaricidal 
Table 1. The treatments and cleaning procedures used on the 323 farms answering the questionnaire about sarcoptic mange eradication programme. The programme had been started at least 7 months before the questionnaire was distributed.

\begin{tabular}{lccc}
\hline & $\begin{array}{c}\text { Farms successful } \\
\text { in eradication, } \\
\mathrm{n}=312\end{array}$ & $\begin{array}{c}\text { Farms unsuccessful } \\
\text { in eradication, } \\
\mathrm{n}=7\end{array}$ & $\begin{array}{c}\text { Farms uncertain } \\
\text { about the result, } \\
\mathrm{n}=4\end{array}$ \\
\hline Treatment: & $282(90 \%)$ & $4(57 \%)$ & $4(100 \%)$ \\
Recommended treatments used & 273 & 4 & 4 \\
$\quad$ 2 ivermectin injections, 14 days interval & 9 & $3(43 \%)$ & \\
$\quad$ phoxim applications, 6 days interval & $26(8 \%)$ & 1 & \\
Non-recommended treatments used & 10 & 1 & \\
$\quad$ Ivermectin and phoxim at the same time & 6 & 1 & \\
One ivermectin injection & 6 & & \\
One ivermectin inj. plus phoxim 1-3 times & 2 & & \\
Phoxim 2 applications & 1 & & \\
2 ivermectin injections, one year interval & 1 & & \\
Stamping out & $4(1 \%)$ & & \\
No information about the treatments & & & \\
& & & \\
Cleaning: & $275(88 \%)$ & & \\
Cleaning and spraying with insecticides & $12(4 \%)$ & & \\
No cleaning or spraying & $19(6 \%)$ & & \\
Different cleaning procedures & $6(2 \%)$ & & \\
No information about cleaning & & & \\
\hline
\end{tabular}

treatments. The median herd size of the 379 farms answering the questionnaire was 40 (range 3-433) sows per herd.

In $312(96 \%)$ out of the 323 farms, where at least 7 months had passed after the start of the programme, the eradication programme had been successful and in $7(2 \%)$ herds it had failed. Four (1\%) owners were uncertain of the outcome. In these herds the eradication programmes had been initiated a median of 19 months (range 7-130) before the questionnaire was distributed.

In $282(90 \%)$ out of the 312 farms judged to have effectuated a successful programme, the local veterinarians had used the recommended treatments. Four out of the 7 unsuccessful farms had used 2 ivermectin injections as recommended and 3 had applied other treatments. Most of the successful farmers (88\%) and all unsuccessful farmers had cleaned and sprayed the environment with insecticides. Table 1 presents the different treatments and cleaning procedures used in detail. When asked for the reasons for the failure, 2 out of the 7 farmers reported a reinfection because of new animals brought into the herd without quarantine, and 5 could not indicate any reason for the failure. The size of the unsuccessful herds was a median of 40 (range 26-60) sows per herd and the programmes had been started on these farms a median of 20 (range 12-27) months earlier. All of these unsuccessful herds had retreated their animals at variable times after the first eradication attempt.

The 312 successful farmers indicated the benefits of the programme in the questionnaire. The most common answers were "animals are more undisturbed, facilities last longer or it is more quiet in the barn " (Table 2). As seen in Table 3, complaints about sarcoptic mange were made 
Table 2. The answers of 312 farmers to the open question in the questionnaire: "What were the benefits of eradicating sarcoptic mange from your farm?" Multiple answers were allowed.

\begin{tabular}{lr}
\hline Benefit & $\begin{array}{r}\text { Number } \\
\text { of farms }\end{array}$ \\
\hline Animals more undisturbed, & 98 \\
$\quad$ facilities last longer, quietness & 61 \\
No need for continuous medications & 59 \\
Animals cleaner & 49 \\
Ability to join the health class & 47 \\
Piglets grow faster & 45 \\
Economical benefits & 41 \\
Healthier pigs, better production & 26 \\
Animal welfare & 15 \\
Management has become easier & \\
Possibility to sell breeding animals, & 11 \\
$\quad$ better market for the animals & \\
Amount of internal parasites and & 10 \\
$\quad$ flies decreased simultaneously & \\
Piglets more vigorous; joint infections, & \\
$\quad$ diarrhoea and tail biting less frequent & 9 \\
No benefits mentioned & 52 \\
TOTAL & 312 \\
\hline
\end{tabular}

in less than one percent of the groups bought by the finishing units. Yet, the number of farms and the feeder pigs sold in the health class increased during the years 1995-1997.

\section{Farm visits}

The 25 farms visited had a median of 47 (range 20-100) sows. On these farms the eradication programmes had been started 20 (7-106) months earlier. One farmer had become uncertain about the result of the programme on his farm, and the local veterinarian had treated the animals with phoxim pour on 4 and 2 weeks before the farm visit (herd S).

All 25 farms were clinically free from mange, all skin scrapings were negative and rubbing indexes were $\leq 0.1$. In 10 farms, all the animals had OD-values lower than 0.175 , the previously recommended cut-off value of the ELISA (Bornstein \& Wallgren 1997). In 14 herds there
Table 3. The follow-up of sarcoptic mange in LSO 2000 health class during 1995-1997. The table presents the number of farms in the health class, the number of feeder pigs sold in the health class, the estimated number of groups of feeder pigs sold in the health class and the number of complaints from the finishing units because of mange.

\begin{tabular}{|c|c|c|c|}
\hline \multirow[b]{2}{*}{ Factor } & \multicolumn{3}{|c|}{ Year } \\
\hline & 1995 & 1996 & 1997 \\
\hline Farrowing units & 379 & 424 & 465 \\
\hline Feeder pigs sold & 208468 & 250336 & 282429 \\
\hline $\begin{array}{l}\text { Estimated number } \\
\text { of groups of feeder }\end{array}$ & & & \\
\hline pigs sold* & 695 & 782 & 856 \\
\hline $\begin{array}{l}\text { Complaints from } \\
\text { finishing units }\end{array}$ & & & \\
\hline because of mange & 5 & 5 & 7 \\
\hline
\end{tabular}

*Counted as number of feeder pigs divided by the average size of a finishing unit collected from the slaughterhouse reports: 300 pigs/herd in 1995, 320 pigs/herd in 1996 and 330 pigs/herd in 1997.

were 1-3 samples with values slightly above this cut-off point. Herd S, which had retreated the animals a few weeks before the visit, had 5 samples above the cut-off point. Recently, a new cut-off point $(0.205)$ based on results obtained from non-SPF mange-free animals has been employed (Bornstein, unpublished). When that new cut-off value was used, there were 7 farms with one sample slightly above the latter cut-off point and the OD-values of the above mentioned 5 animals of herd $\mathrm{S}$ were still above the latter cut-off (Table 4).

\section{Discussion}

The large-scale eradication programme against sarcoptic mange proved to be successful. A great number of herds joined the programme. A very high percentage of the farmers believed in its success. Further evidence was obtained both through the farm visits and the regular control in the health class. The opinions of the farmers about the herd disease status are usually consid- 
Table 4. ELISA results from 25 herds visited after sarcoptic mange eradication programme. The values are presented as medians (minimum-maximum): Time, months = time period between the beginning of the eradication programme and the herd visit, OD-values = the level of serum antibodies presented as optical density (OD) values, $\mathrm{N}=$ number of samples from sows and gilts. Two different cut-off values are used, 0.175 and 0.205 . In herd $S^{*}$ the animals had been retreated 2 and 4 weeks before the herd visit, all other farmers thought that the eradication programme had succeeded.

\begin{tabular}{|c|c|c|c|c|c|}
\hline $\begin{array}{l}\text { Herd, } \\
n=25\end{array}$ & $\begin{array}{c}\text { Time } \\
\text { (months) }\end{array}$ & OD-values & $\mathrm{N}$ & $\begin{array}{l}\text { Number of samples } \\
\mathrm{OD}>0.175 \text { (values) }\end{array}$ & $\begin{array}{l}\text { Number of samples } \\
\text { OD }>0.205 \text { (values) }\end{array}$ \\
\hline $\mathrm{L}$ & 25 & $0.053(0.025-0.106)$ & 19 & 0 & 0 \\
\hline A & 7 & $0.054(0.024-0.075)$ & 19 & 0 & 0 \\
\hline AA & 17 & $0.063(0.027-0.096)$ & 20 & 0 & 0 \\
\hline Q & 24 & $0.063(0.020-0.125)$ & 20 & 0 & 0 \\
\hline$\ddot{\mathrm{A}}$ & 18 & $0.067(0.044-0.112)$ & 20 & 0 & 0 \\
\hline D & 15 & $0.069(0.047-0.119)$ & 20 & 0 & 0 \\
\hline $\mathbf{J}$ & 20 & $0.074(0.048-0.114)$ & 20 & 0 & 0 \\
\hline $\mathrm{X}$ & 37 & $0.078(0.033-0.136)$ & 20 & 0 & 0 \\
\hline $\mathrm{N}$ & 21 & $0.085(0.033-0.153)$ & 20 & 0 & 0 \\
\hline $\mathrm{C}$ & 106 & $0.087(0.063-0.171)$ & 19 & 0 & 0 \\
\hline $\mathrm{R}$ & 18 & $0.076(0.043-0.180)$ & 20 & $1(0.180)$ & 0 \\
\hline $\mathrm{O}$ & 18 & $0.078(0.035-0.177)$ & 19 & $1(0.177)$ & 0 \\
\hline $\mathrm{K}$ & 9 & $0.092(0.037-0.199)$ & 20 & $1(0.199)$ & 0 \\
\hline $\mathrm{E}$ & 18 & $0.094(0.041-0,184)$ & 20 & $1(0.184)$ & 0 \\
\hline $\mathrm{F}$ & 27 & $0.100(0.038-0.181)$ & 18 & $1(0.181)$ & 0 \\
\hline $\mathbf{P}$ & 32 & $0.101(0.051-0.177)$ & 19 & $1(0.177)$ & 0 \\
\hline B & 22 & $0,099(0.044-0.194)$ & 15 & $2(0.176 \& 0.194)$ & 0 \\
\hline$\AA$ & 21 & $0.073(0.035-0.220)$ & 20 & $1(0.220)$ & $1(0.220)$ \\
\hline I & 19 & $0.076(0.048-0.208)$ & 19 & $1(0.208)$ & $1(0.208)$ \\
\hline $\mathbf{M}$ & 24 & $0.083(0.044-0.246)$ & 20 & $1(0.246)$ & $1(0.246)$ \\
\hline W & 20 & $0.085(0.052-0.252)$ & 20 & $1(0.252)$ & $1(0.252)$ \\
\hline $\mathrm{H}$ & 18 & $0.092(0.036-0.253)$ & 20 & $1(0.253)$ & $1(0.253)$ \\
\hline $\mathrm{Y}$ & 14 & $0.088(0.043-0.250)$ & 20 & $2(0.202 \& 0.250)$ & $1(0.250)$ \\
\hline$Z$ & 23 & $0.102(0.055-0.221)$ & 20 & $3(0.180,0.187 \& 0.221)$ & $1(0.221)$ \\
\hline Median & 20 & $0.076(0.020-0.253)$ & 20 & 1 & 0 \\
\hline (Range) & $(7-106)$ & & $(15-20)$ & $(0-3)$ & $(0-1)$ \\
\hline \multirow[t]{2}{*}{$\mathrm{S}^{*}$} & 20 & & & & \\
\hline & $\begin{array}{l}\text { Retreat- } \\
\text { ment }\end{array}$ & $0.121(0.054-0.353)$ & 20 & $\begin{array}{l}5(0.232,0.235 \\
0.275,0.310 \& 0.353)\end{array}$ & \\
\hline
\end{tabular}

ered as unreliable information, but in the case of swine sarcoptic mange it is believed to be less so (Davies et al. 1996). Apart from recent infections, it is unlikely that herd infections would go undetected in untreated populations (Dobson \& Davies 1992). In addition, the opinions of the owners in our study are supported by regular visits by the local veterinarians mon- itoring for signs of the disease. The reported length of the incubation period in experimental studies has ranged from 2-3 weeks (Sheahan 1974) up to 7-11 weeks (Cargill \& Dobson 1979). Keller et al. (1972) reported that in natural infection the clinical symptoms appeared 3-4 months after bringing S.scabiei infected animals into 4 SPF-herds. Clinical signs devel- 
oped in mange-free pigs from $4 \frac{1}{2}$ to 13 weeks after exposure to pens previously occupied by S.scabiei infected pigs (Smith 1986). According to our experience the farmers become aware of mange infection within half a year after a reinfection or a failure in an eradication programme has occurred. By that time the clinical signs will reappear, because acaricides are no longer used. In the present study the follow-up time after the eradication had been long enough in the herds to reveal possible failures. The high response rate $(100 \%)$ to the survey leaves no room for speculation that the farmers with unsuccessful eradication programmes could have been non-respondents. In addition, the owners of the finishing units were very likely to report all mange suspects to the quality officer, because they had paid a higher price for the health class feeder pigs and there was a warranty against mange given by LSO.

Our study shows that it is possible to create a swine health class with a large number of mange-free herds by eradicating the agent with recommended treatments. Some veterinarians had used other methods than those recommended and in spite of that they had succeeded. One possible explanation is that some of the farms may not have been mange positive from the beginning and the eradication programme had been undertaken just to be sure. However, the percentage of the farms which had never been infected by mange according to the questionnaire (9\%) is well in accordance with a previous epidemiological study in the same area (Tuovinen et al. 1994). Some farms seem to have succeeded even with modified methods. It is notable that almost half of the unsuccessful eradication attempts had been made using methods other than those recommended by LSO. Unfortunately, the failure of the herds could not be verified because of the retreatment of the animals. Some of the herds may have reused acaricides unnecessarily. The need for cleaning and spraying the pens with insecticides is under discussion. In this study, farmers who had not done any cleaning still had successful eradications. It has been shown that using effective acaricides without applying any desinfection of the environment is enough to successfully carry out eradication of $S$. scabiei infections in swine herds (Cargill et al. 1996, Jacobsson et al. 1999). However, it is paramount to apply strict biosecurity measures in order to prevent reinfection.

Producers have tolerated mange infections in their herds in the past and control measures have often been haphazardly applied, partly because of the covert nature of the losses and the fact that clinical signs of hypersensitive mange (pruritus) have usually been thought to be normal (Cargill et al. 1997). The farmers we studied were satisfied, and only after the eradication of mange did they realise the difference.

Farm visits confirmed the success of the eradications in all except one herd. Unfortunately, the failure in this herd could not be verified because of the retreatment of the animals. We used all of the common methods available for mange diagnosis during the farm visits and did not find any infected herds. Still, the divergent serological responses obtained in that herd strongly suggest that it had actually been reinfected and that acaricidal treatment was indicated.

The absence of clinical signs of mange, negative skin scrapings and low rubbing indexes indicated strongly that the farms were free from sarcoptic mange. In general, clinical signs such as pruritus have appeared to be a better indicator of scabies infection than the results of skins scrapings, especially in adult animals (Courtney et al. 1983). Skin scrapings alone have not been found to be reliable in proving freedom from sarcoptic mange (Bornstein et al. 1994, Lambers 1994, Bornstein \& Wallgren 1997). They would be of value only in the chronic form of the disease according to Cargill \& 
Dobson (1979), who also claimed that in pigs with the acute form of sarcoptic mange, evidence of rubbing, hair loss, abrasions and urticaria is a more reliable guide than examination of skin scrapings. Under experimental conditions, rubbing and scratching episodes have been a good indicator of the presence of $S$. scabiei in pigs (Cargill \& Dobson 1979, Hollanders et al. 1995) with a rubbing index greater than 0.4 considered to be a good indicator of mange (Madsen 1988). All the farms in the present study had rubbing indexes below 0.1 .

The determination of antibody levels is a possible tool in monitoring the efficacy of eradication programmes. Serum antibodies to the mite have been demonstrated by an ELISA 5-7 weeks after an experimental infection (Bornstein \& Zakrisson 1993). The cut-off OD value for the test to discriminate positive from negative animals was previously set at 0.175 based on SPF pigs. The cut-off values for 3 different age categories (10 to 12 weeks, 16 to 20 weeks and sows) were $0.077,0.123$ and 0.177 , respectively (Bornstein \& Wallgren 1997). In recent studies using non-SPF, mange free animals, the cut-off value increased to 0.205 for sows (Bornstein, personal communication). Antibody levels decrease below the cut-off value in 10 to 12 months after eradication of mange in adult animals (Bornstein et al. 1994), but some individual animals may retain antibodies for a longer period of time (Bornstein, personal communication). In growing pigs, the decrease of the specific antibodies following the treatment is quicker (Bornstein et al. 1994). The background OD values may differ between animals bred in different environments (Greiner \& Böhning 1994, Bornstein \& Wallgren 1997) or in animals of different ages (Bornstein \& Wallgren 1997). Unspecific reactions may also occur, if animals are sampled close to vaccinations because of high immunoglobulin levels. There are several different species of mites in the environment of pigs. Studies have demonstrated that there is immunologic cross reactivity between Sarcoptes scabiei and the allergy causing house-dust mites Dermatophagoides pteronyssimus and D. farinae (Falk et al. 1981, Arlian et al. 1988, 1991). The median OD value in our study for 24 clinically mange-free herds was 0.076 . These herds were likely to be free from mange in spite of the few increased OD values. After the present study was performed Jacobsson et al. (1999) recommended that the best age group of pigs be sampled for determining antibodies to $\mathrm{S}$. scabiei is $10-12$ weeks old piglets born after an eradication programme on a farm. Piglets aged less than 10 weeks should not be sampled for monitoring purposes because of possible disturbance of maternal immunity (Bornstein \& Wallgren 1997). Also Hollanders et al. (1997) recommended that piglets or fatteners born after execution of an eradication programme should be sampled in order to avoid positive results due to the specific antibodies present as a result of pre-treatment mange infections. Sampling young animals has also another advantage: there is no need to wait for a year before tests for the success of the programme can be initiated. However, employing adult animals in monitoring the results of eradication programmes is feasible. One has to take into consideration that a few individuals may retain their specific antibodies for longer periods as shown in the present study.

In conclusion, this study demonstrates that it is possible in modern pig production to progress from disease control to disease eradication on a large scale in the case of sarcoptic mange and that monitoring of such programmes can be done by serology.

\section{References}

Arlian LG, Vyszenski-Moher DL, Gilmore AM: Cross-antigenicity between Sarcoptes scabiei and the house dust mite, Dermatophagoides farinae (Acari: Sarcoptidae and Pyroglyphidae). J. 
Med. Entomology 1988, 25, 240-247.

Arlian LG, Vyszenski-Moher DL, Ahmed SG, Estes $S A$ : Cross-antigenicity between the scabies mite, Sarcoptes scabiei and the house mite Dermatophagoides pteronyssimus. J. Invest. Dermatol. 1991, 96, 3, 349-354.

Bornstein S: Sarcoptes scabiei infections of the domestic dog, red fox and pig. Clinical and serodiagnostic studies. Thesis, 1995, Uppsala, Sweden, $63 \mathrm{pp}$.

Bornstein S, Zakrisson G: Clinical picture and antibody response in pigs infected by Sarcoptes scabiei var. suis. Vet. Dermatol. 1993, 4, 123131.

Bornstein S, Wallgren P: Serodiagnosis of sarcoptic mange in pigs. Vet. Rec. 1997, 141, 8-12.

Bornstein S, Fellström C, Thebo P, Wallgren P: Eradication of sarcoptic mange in a herd of pig monitored by skin scrapings and ELISA. Proceedings of the 1994-IPVS Congress in Bangkok, 1994, Thailand, 251. (Abstr).

Cargill CF, Dobson KJ: Experimental Sarcoptes scabiei infestation in pigs: (1) pathogenesis. Vet. Rec. 1979, 104, 11-14.

Cargill CF, Moore MJ, Pointon AM, Garcia R: A retrospective evaluation based on slaughter monitoring of using ivermectin to control and eradicate sarcoptic mange. Proceedings of the 1996-IPVS Congress in Bologna, Italy, 356. (Abstr.)

Cargill CF, Pointon AM, Davies PR, Garcia R: Using slaughter inspections to evaluate sarcoptic mange infestation of finishing swine. Vet. Parasitol. 1997, 70, 191-200.

Courtney CH, Ingalls WL, Stitzlein SL: Ivermectin for the control of swine scabies: relative values of prefarrowing treatment of sows and weaning treatment of pigs. Am. J. Vet. Res. 1983, 44, 1220-1223.

Davies PR, Bahnson PB, Grass JJ, Marsh WE, Garcia R, Melancon J, Dial GD: Evaluation of the monitoring of papular dermatitis lesions in slaughtered swine to assess sarcoptic mite infestation. Vet. Parasitol. 1996, 62, 143-153.

Dobson KJ, Davies PR: External parasites. In: A.D. Leman, B.E. Straw, W.L. Mengeling, S. D'Allaire and D.J. Taylor (eds.): Diseases of swine. Ames, Iowa, Iowa State University Press, 1992, pp. 668672.

Falk ES, Dale S, Bolle R, Haneberg B: Antigens common to scabies and house dust mites. Allergy 1981, 36, 233-238.

Greiner M, Böhning D: Notes about determining the cut-off value in enzyme linked immunosorbent assay (ELISA) - Reply. Prev. Vet. Med. 1994, 20 , 307-310.

Henriksen SA, Ebbesen TJ: Udryddelse af skab i to sobesaetninger. Afsluttende undersoegelser (Eradication of mange mite in two sow herds). Dansk Vet. Tidskr. 1987, 70, 530-533.

Hogg A: The control and eradication of sarcoptic mange in swine herds. Agri-Practice 1989, 10, 8 10.

Hollanders W, Harbers AH, Huige JC, Monster P, Rambags PGM, Hendrikx WML: Control of Sarcoptes scabiei var. suis with ivermectin: influence on scratching behaviour of fattening pigs and occurrence of dermatitis at slaughter. Vet. Parasitol. 1995, 58, 117-127.

Hollanders W, Vercruysse J, Raes S, Bornstein S: Evaluation of an enzyme-linked immunosorbent assay (ELISA) for the serological diagnosis of sarcoptic mange in swine. Vet. Parasitol. 1997, 69, 117-123.

Jacobsson M, Bornstein S, Wallgren P: The efficacy of simplified eradication strategies against sarcoptic mange mite infections in swine herds monitored by an ELISA. Vet. Parasitol. 1999, 81, 249-258.

Jensen JC: Experiences with short medication periods using tiamulin for eradication of swine dysentery, and ivermectin for eradication of mange. Proceedings of the 1988-IPVS Congress in Rio De Janeiro, Brazil, 269 (Abstr.).

Jensen JCE, Havn CV, Lind $O$ : Kombineret skab- og dysenterisanering (Combined eradication of mange and dysentery). Dansk Vet. Tidskr. 1988, $71,105-112$.

Keller H, Eckert J, Trepp HC: Zur Tilgung der Sarcoptes - Räude beim Schwein. (Eradication of sarcopfic mange in swine). Schweiz. Arch. Tierheilk. 1972, 114, 573-582.

Lambers JH: Elimination of Sarcoptes scabiei in a dutch pig breeding herd. Proceedings of the 1994-IPVS Congress in Bangkok, Thailand, 252. (Abstr.).

Madsen $S A$ : Eradication of scab in pigs. Udryddelse af skab i svinebesaetninger. Behandlingsforsog med phoxim i pour-on form (Eradication of scab in pigs. Experiments in treating with phoxim in pour-on form). Dansk Vet. Tidskr. 1988, 71, 1159-1167.

Martineau GP, Van Neste D, Charette R: Pathophysiology of sarcoptic mange in swine - Part I. Comp. Cont. Educ. Pract. Vet. 1987a, 9, F51F59.

Martineau GP, Van Neste D, Charette R: Pathophy- 
siology of sarcoptic mange in swine - Part II. Comp. Cont. Educ. Pract. Vet. 1987b, 9, F93F98.

Morsy GH, Gaafar SM: Responses of immunoglobulin-secreting cells in the skin of pigs during Sarcoptes scabiei infestation. Vet. Parasitol. 1989, 33, 165-175.

Nöckler $K$, Matthes HF, Hiepe T, Ziegler H: Nachweis von Anti-Sarcoptes suis-IgG in Blutserum neonatal mit Sarcoptes milben infizierter Ferkel mit dem indirekten ELISA. (Demonstration of anti-Sarcoptes suis-IgG with indirect ELISA in senum of piglets infected neonatally with Sarcoptic mange mites). Mh. Vet.-Med. 1992, 47, 415-421.

Oksanen A: Sian kapi - mikä se on ja mitä tehdä sille? (Sarcoptic mange in swine - What to do?). Finnish Vet. J. 1989, 95, 64-68.

Oksanen A, Tuovinen VK: Sikalan kapisaneeraus foksiimilla (Sarcoptic mange eradication in piggeries with phoxim). Finnish Vet. J. 1990, 96, 68-71.

Sheahan BJ: Experimental Sarcoptes scabiei infetion in pigs: Clinical signs and significance of infection. Vet. Rec. 1974, 94, 202-209.

Smith HJ: Transmision of Sarcoptes scabiei in swine by fomites. Can. Vet. J. 1986, 27, 252-254.

Tuovinen VK: Control of swine diseases of slaughterhouse activities: epidemiological studies. Thesis, 1994. College of Veterinary Medicine, Helsinki, $61 \mathrm{pp}$.

Tuovinen VK, Levonen K, Gröhn Y, Straw BE: The prevalence of some economically important swine diseases in farrowing units in Southwestern Finland. Prev. Vet. Med. 1994, 19, 85-100.

Tuovinen VK, Gröhn YT, Straw BE: Farrowing unit housing and management factors associated with diseases and disease signs of importance for feeder pig quality. Acta Agric. Scand., Sect. A, Anim. Sci. 1997a, 47, 117-125.

Tuovinen VK, Heinonen M, Suutari E: LSO 2000 quality chain produces non-medicated pork. Proceeding of the Int. Soc. for An. Hyg. 1997b, Helsinki, Finland 1, 180-183. (Abstr.).

Wooten EL, Gaafar SM: Detection of serum antibodies to sarcoptic mange mite antigens by the passive hemagglutination assay in pigs infested with Sarcoptes scabiei var. suis. Vet. Parasitol. 1984, $15,309-316$.

\author{
Sammanfattning \\ Skabbsanering bland svinbesättningar $i$ en hälso- \\ klass.
}

Resultaten av skabbsanering (Sarcoptes scabiei) studerades bland svinbesättningar tillhörande hälsoklassen LSO 2000 där besättningarna skall vara fria från skabb, enzootisk pneumoni, svindysenteri och nyssjuka. De lokala veterinärerna fick ett råd att utrota skabben med antingen 2 ivermectin injektioner med 14 dagars mellanrum eller 3 behandlingar med phoxim med 6 dagars mellanrum innan besättningarna kunde ingå i ovannämnda hälsoklass. Undersökningen omfattade ett frågeformulär för djurägarna, besättningsbesök och regelbunden kontroll av hälsoklassen. Ett frågeformulär sändes till alla de 379 gårdar vilkas besättning ingick i hälsoklassen. 323 djurägare hade initierat skabbsaneringen åtminstone 7 månader innan frågeformuläret delades ut, och 96\% av dem ansåg att skabbsaneringen hade lyckats. På $90 \%$ av besättningarna med positivt saneringsresultat hade de lokala veterinärerna använt rekommenderade metoder, och de flesta av djurägarna ( $88 \%$ ) hade rengjort och sprayat omgivningen med insekticider. På 3 av 7 gårdar där saneringen misslyckats hade man använt andra metoder än de rekommenderade.

Klådindekset noterades, och det var $<0.1$ i alla kontrollerade besättningar, vilket var en indikation på skabbfrihet. Av 15-20 suggor eller gyltor per besättning togs ett skrapprov och det fanns inga spår av $S$. scabiei i dem. Ett blodprov togs av samma djur och deras antikroppar mot $S$. scabiei fastställdes med indirekt ELISA. Alla besättningar förutom en visade låga OD-värden $\mathrm{i}$ de flesta proven. Ägaren av ovannämnda besättning var osäker på sina grisars skabbstatus och djuren på hans gård hade nyligen behandlats igen. Reklamationer på grund av skabb var sällsynta bland de gårdar som hade köpt förmedlade grisar tillhörande hälsoklassen. Undersökningen bevisar att det är möjligt att utarbeta ett skabbsaneringsprogram med stort antal deltagare, både djurägare och veterinärer. Det är möjligt att utrota skabb inte bara på besättningsnivå utan också på populationsnivå. ELISA testet visade sig vara användbart $\mathrm{i}$ kontroll av skabbsanering.

(Received May 21, 1999; accepted November 10, 1999).

Reprints may be obtained from: M. Heinonen, University of Helsinki, Pohjoinen pikatie 800, FI-04920 Saarentaus, Finland. E-mail: mlheinon@mappi.helsinki.fi, tel: +358-400-687 915, fax: +358-19-6851 181. 